\title{
Feeding habits of juvenile surface-migratory myctophid fishes (family Myctophidae) in the Kuroshio region of the western North Pacific
}

\author{
Hikaru Watanabe $^{1, *}$, Kouichi Kawaguchi ${ }^{2}$, Amane Hayashi ${ }^{2}$ \\ ${ }^{1}$ National Research Institute of Far Seas Fisheries (Japan Science and Technology Corporation), 5-7-1 Orido Shimizu-shi, \\ Shizuoka 424-8633, Japan \\ ${ }^{2}$ Ocean Research Institute, University of Tokyo, 1-15-1 Minamidai Nakano-ku, Tokyo 164-8639, Japan
}

\begin{abstract}
We examined the diets and nighttime feeding chronologies of the most abundant juvenile surface-migratory myctophid fishes in the Kuroshio waters of the western North Pacific: Myctophum asperum, M. nitidulum, Symbolophorus evermanni and Centrobranchus brevirostris. Samples were collected from water 0 to $1 \mathrm{~m}$ deep at night from January to March during 10 yr between 1961 and 1992. The 4 species exhibited resource partitioning by having different main prey items at night in the top $1 \mathrm{~m}$ layer. $M$. asperum fed mainly on appendicularians, M. nitidulum on copepods and amphipods, S. evermanni on euphausiids and $C$. brevirostris on pteropods. They also had speciesspecific peak feeding hours, demonstrated by the different hours during which each species had the greatest wet weight of stomach contents (percentage of body weight): 24:00 to 01:00 $\mathrm{h}(5.1 \%)$ and 02:00 to $03: 00 \mathrm{~h}(4.0 \%)$ for $M$. asperum; $03: 00$ to $04: 00 \mathrm{~h}(7.3 \%)$ for $M$. nitidulum; $04: 00$ to $05: 00 \mathrm{~h}$ $(3.9 \%)$ for $S$. evermanni; and $20: 00$ to $21: 00 \mathrm{~h}, 22: 00$ to $23: 00 \mathrm{~h}$ and $04: 00$ to $05: 00 \mathrm{~h}(4.6,5.3$ and $3.8 \%$, respectively) for $C$. brevirostris. These results suggest that myctophids that migrate to the surface reduce trophic competition by specializing in different food organisms. We observed 2 and 3 feeding peaks for species that feed on gelatinous plankton (M. asperum and $C$. brevirostris, respectively), compared with 1 peak for crustacean feeders (S. evermanni and $M$. nitidulum). We also estimated the impact on zooplankton of nocturnal feeding by these 4 species.
\end{abstract}

KEY WORDS: Myctophid fish $\cdot$ Diel vertical migration $\cdot$ Surface migrant $\cdot$ Feeding habit $\cdot$ Feeding chronology $\cdot$ Resource partitioning $\cdot$ Feeding impact $\cdot$ Kuroshio region

\section{INTRODUCTION}

Surface migratory myctophid fishes that migrate at night from the mesopelagic layer up to the surface are commonly collected there in neuston nets. A 5 to 10 min tow often yields several species (Ogawa 1961, Hattori 1964, Kawaguchi et al. 1972, Watanabe \& Kawaguchi 1999). These migrants to surface waters are closely related species and genera of the subfamily Myctophinae (Paxton 1972). This surface migratory

*E-mail: hikaru1@affrc.go.jp behavior starts after transformation from larvae to juveniles. The larvae are distributed in the upper $200 \mathrm{~m}$ layer both during the daytime and at night (Loeb 1979, 1980, Moser \& Smith 1993). Myctophid fishes are thought to migrate to the surface to feed in the productive epipelagic zone, which contributes to their flourishing abundance in the open sea. Generally, the tropical and subtropical species feed mainly in the epipelagic zone at night (Clarke 1978, Hopkins \& Baird 1985, Kinzer \& Schulz 1985), while the subarctic and transitional water species feed during both night and day (Tyler \& Pearcy 1975, Pearcy et al. 1979, Moku et al. 2000). In the Kuroshio region, Myctophum asperum,

(ㄷ) Inter-Research $2002 \cdot$ www.int-res.com 


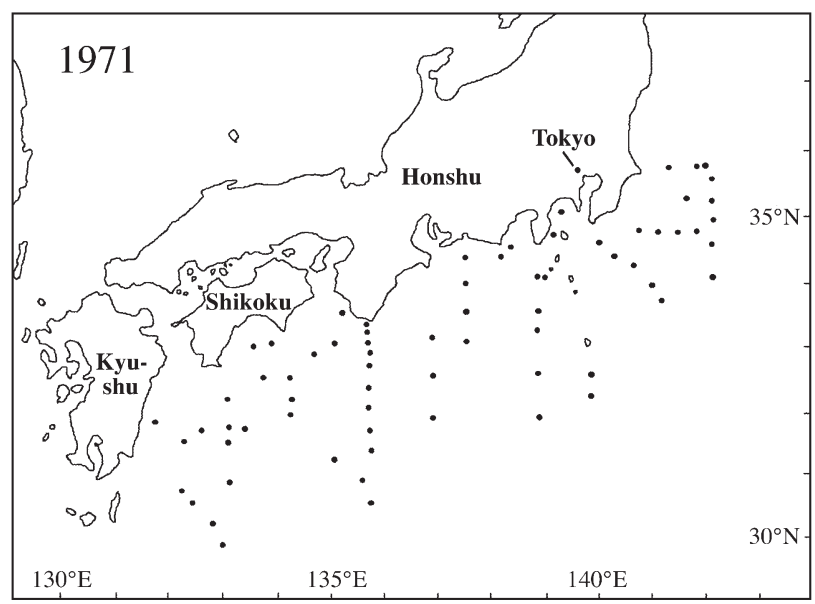

Fig. 1. Sampling localities in 1971

M. nitidulum, Symbolophorus evermanni and Centrobranchus brevirostris are the 4 most abundant of such migratory species (Hattori 1964, Watanabe 1998). There are considerable data on the feeding habits of myctophid fish that migrate to midwaters (e.g. Merrett \& Roe 1974, Baird et al. 1975, Clarke 1978, 1980, Kinzer \& Schulz 1985, Hopkins \& Gartner 1992), but data for surface migratory species are limited (Gorelova 1975, 1984, Hopkins \& Gartner 1992).

In this study, we aimed to determine the main diet and nighttime feeding chronology of the juvenile myctophid species Myctophum asperum, M. nitidulum, Symbolophorus evermanni and Centrobranchus brevirostris, which migrate to the upper $1 \mathrm{~m}$ layer at night in the Kuroshio Current region. We also estimated the impact of nocturnal feeding by these 4 species on the biomass of epipelagic zooplankton.

\section{MATERIALS AND METHODS}

All samples were collected in the Kuroshio region of the western North Pacific ( 29 to $36^{\circ} \mathrm{N}, 130$ to $144^{\circ} \mathrm{E}$ ) from January to March during each of the 10 yr: 1961, 1964, 1968, 1971, 1973, 1977, 1980, 1984, 1988 and 1992. Typical sampling coverage is shown in Fig. 1. Sampling was conducted at night, at 58 to 131 stations (on average, 95) per year during the Japanese Fisheries Agency's survey of eggs and larvae of commercially important fishes. To collect samples, we used a conical plankton net (mouth opening, $130 \mathrm{~cm}$ diameter; Maruchi type A net; Nakai 1962, Watanabe \& Kawaguchi 1999) placed within $1 \mathrm{~m}$ of the surface at shipside, towed at $1 \mathrm{~m} \mathrm{~s}^{-1}$ ( $2 \mathrm{knots}$ ) for 5 to $10 \mathrm{~min}$. Samplings were made consecutively at 1 to $3 \mathrm{~h}$ intervals along the grid line designed to cover the average Kuroshio area, resulting in variation in sampling time and distance from Japan but which were averaged each year.

We studied the feeding habits of individuals that were from 10 to $30 \mathrm{~mm}$ in standard length (SL). Fish of this size range were the most frequently caught, and formed the first mode in the size frequency distribution and are considered as 0+ years old (Watanabe 1998). After measuring wet weights (wet wt) of the body of each fish and its stomach contents, we identified each prey item in the stomach to the lowest possible taxonomic level and also measured its wet wt. Additionally, we measured total length and width for prey specimens collected in 1971 and 1988, when more than 25 individuals were collected for each of the 4 myctophid species.

We calculated the stomach content index (SCI), i.e. the mean wet wt of stomach content given as a percentage of body weight, for 23 to 35 individuals for each hour between 19:00 and 05:00 h. For hours during which the sample size was fewer than 20 individuals, we pooled the sample with specimens collected in other years $(1972,1974$ to $1976,1985,1986)$. We defined the feeding peak as the hour during which the SCI was statistically higher than the values immediately before or after, and higher than the mean SCI for the night. When the peak spanned $2 \mathrm{~h}$, we tested whether the values before and after the peak were significantly lower.

Lastly, we measured the gill raker interval on the lower branch of the first gill arch for each species except Centrobranchus brevirostris, whose degenerated gill rakers are adapted to pteropod feeding (Bekker 1966).

\section{RESULTS}

\section{Prey group composition}

The 4 species exhibited resource partitioning, although prey composition was sometimes biased due to the small sample size (Fig. 2). No remarkable geographical difference was observed in diets of the 4 species in the years when large sample size was available. Over the $10 \mathrm{yr}$ sampled, unidentifiable stomach content weights were $9.2 \pm 5.4 \%$ (mean $\pm \mathrm{SD}$ ), $4.3 \pm 3.4 \%, 8.0 \pm$ $8.1 \%$ and $7.3 \pm 5.9 \%$ of the total stomach contents for Myctophum asperum, Symbolophorus evermanni, M. nitidulum, and Centrobranchus brevirostris, respectively. These prey items were excluded from Fig. 2.

\section{Myctophum asperum}

This species mainly ate appendicularians and a variety of the crustaceans available in the habitat (Fig. 2a). Appendicularians were the most common prey in 6 of 
the 10 years $(1964,1968,1973,1980,1984$ and 1992) and accounted for 36 to $86 \%$ of the total weight of identified stomach contents (Fig. 2a). In 1961 and 1971, copepods were the most common prey item (53 and $32 \%$, respectively); the next most common was appendicularians in 1961 and amphipods in 1971 (47 and 29\%, respectively). Euphausiids were the most common prey item in 1977 and 1988 (45 and $41 \%$, respectively), followed by appendicularians (28 and 32\%, respectively). In 1964, 1973 and 1980, amphipods were the second most common prey item (22 to $34 \%$ ) (Fig. 2a).

\section{Symbolophorus evermanni}

Euphausiids and amphipods were the main prey items found in identified stomach contents, indicating that this fish depends on larger-sized crustaceans (Fig. 2b). Euphausiids were the most common prey eaten during all 10 years, accounting for 44 to $100 \%$ of the total weight of stomach contents. Amphipods accounted for 0 to $29 \%$ and copepods for 0 to $27 \%$ (Fig. 2b).

\section{Myctophum nitidulum}

This species preyed mostly on copepods and amphipods with occasional euphausiids and appendicularians (Fig. 2c). During the 10 years, copepods and amphipods were the first or second most common prey items, accounting for 66 to $100 \%$ of the total weight of identified stomach contents. Euphausiids constituted 6 to $15 \%$ in 1971, 1977 and 1980; appendicularians contributed 12 to $34 \%$ in 1964, 1984 and 1988 (Fig. 2c).

\section{Centrobranchus brevirostris}

This species fed exclusively on gelatinous zooplanktons, i.e. pteropods and appendicularians (Fig. 2d). Pteropods were the most abundant prey item, being 65 to $100 \%$ of the total weight of identified stomach contents in 9 of the 10 years; whereas appendicularians accounted for 2 to $35 \%$ in 7 of the 10 years. These 2 prey groups accounted for more than $83 \%$ of the total prey in 9 of the 10 years, but only 33 in 1980 (Fig. 2d). Copepods, euphausiids and amphipods were occasionally eaten and accounted for 0 to 67,0 to 11 and 0 to $3 \%$ of the total prey, respectively.

\section{Size of prey species or genera}

We identified 11 prey species belonging to 14 genera in 416 stomachs of the 4 myctophid species collected in 1971 and 1988 (Table 1). These species comprise much of the zooplankton community found in the subsurface waters in the Kuroshio region at night (Kidachi \& Ito 1979, Kidachi et al. 1983, Hirota et al. 1984, Nakata 1997).

The genera and species of copepods found in Myctophum asperum and $M$. nitidulum were generally similar. Unique to M. nitidulum, however, were Candacia (a) Myctophum asperum

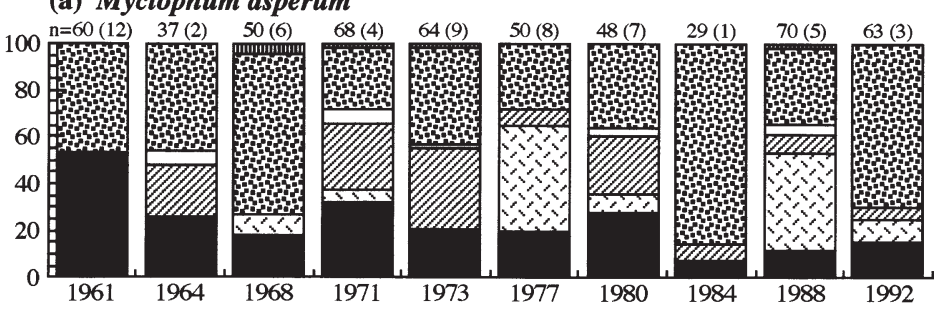

(b) Symbolophorus evermanni

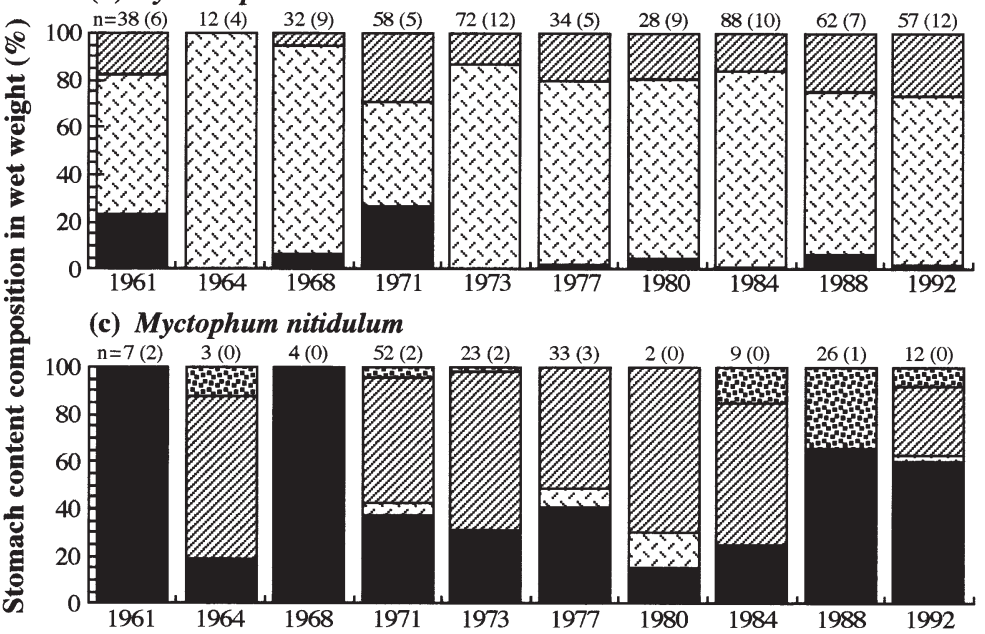

(d) Centrobranchus brevirostris

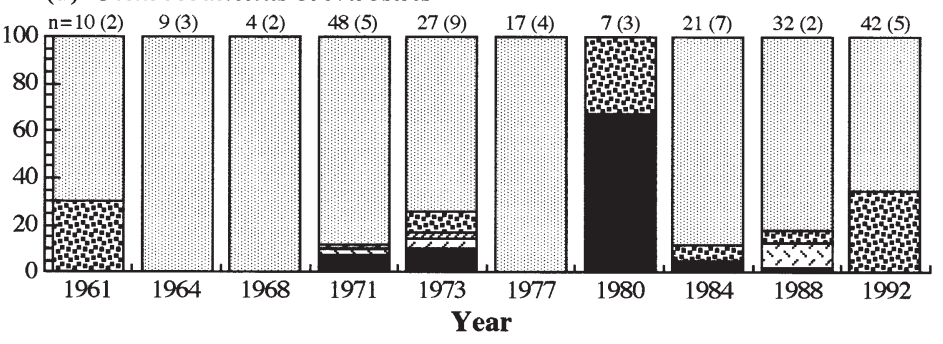

Copepods $\square$ Euphausiids $\square$ Amphipods $\square$ Ostracods Pteropods 페I Others (Chaetognaths, Fish larvae)

Fig. 2. Wet weight composition of prey groups for the 4 myctophid species in the Kuroshio region: (a) Myctophum asperum; (b) Symbolophorus evermanni; (c) Myctophum nitidulum; and (d) Centrobranchus brevirostris. $\mathrm{n}$ indicates the number of stomachs examined (number of empty stomachs in parentheses) 


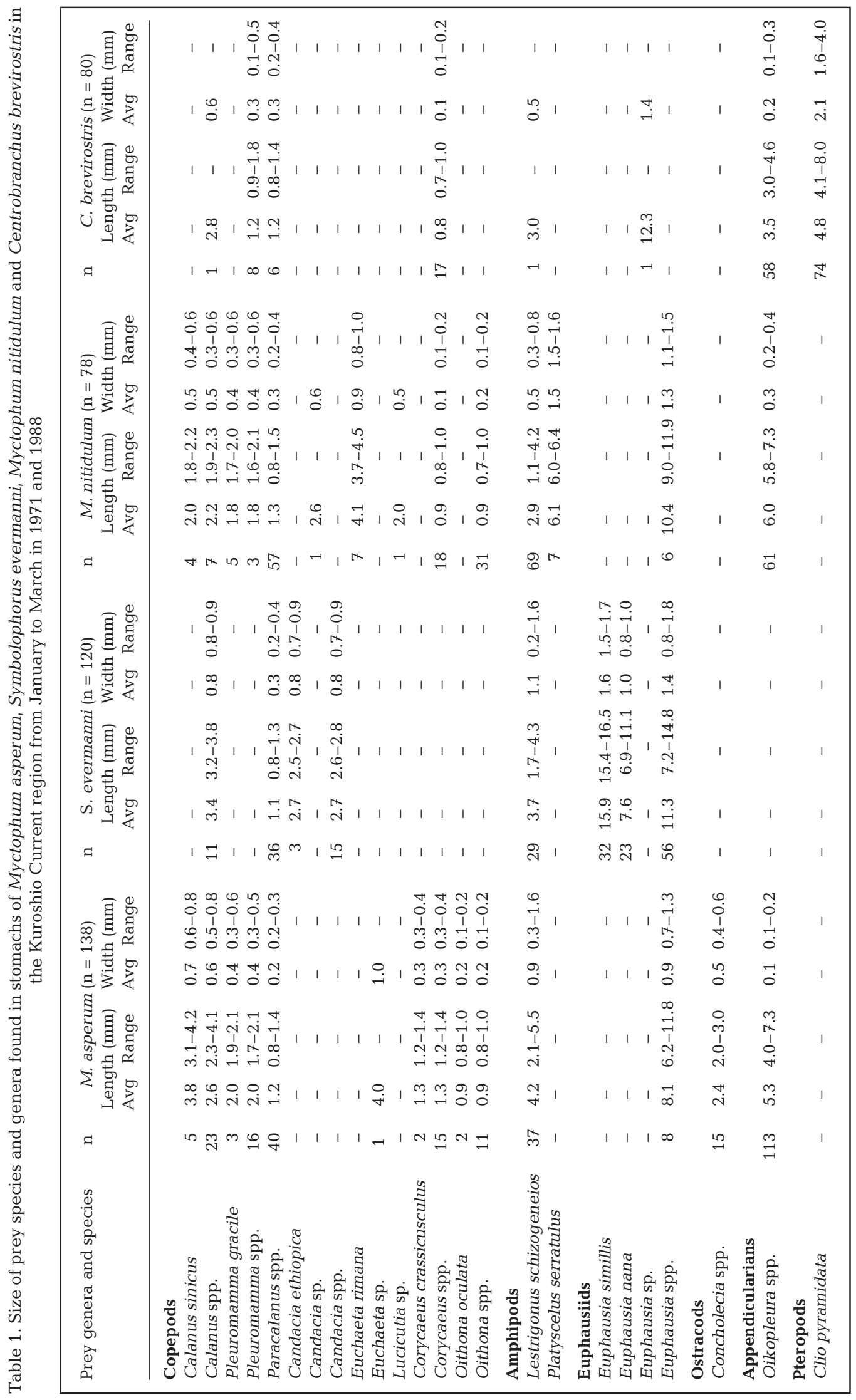




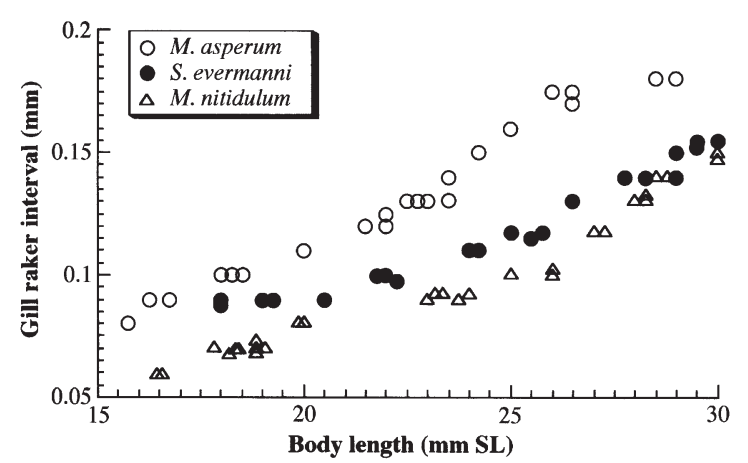

Fig. 3. Slit width of gill rakers on a lower branch of the first gill arch in relation to body length in Myctophum asperum, Symbolophorus evermanni and $M$. nitidulum

\section{Gill raker interval}

Gill raker intervals (slit width) were 0.08 to $0.18 \mathrm{~mm}$, 0.09 to $0.16 \mathrm{~mm}$ and 0.06 to $0.15 \mathrm{~mm}$ for Myctophum asperum, Symbolophorus evermanni and M. nitidulum individuals of 15.0 to $30.0 \mathrm{~mm} \mathrm{SL}$, respectively (Fig. 3). sp., Euchaeta rimana and Lucicutia sp. Although the size ranges of Pleuromamma, Paracalanus and Oithona spp. individuals eaten by $M$. asperum and $M$. nitidulum overlapped (Table 1), individuals eaten by $M$. asperum were significantly larger (mean $\pm \mathrm{SD}, 20.9 \pm 3.3 \mathrm{~mm} \mathrm{SL}$ ) than those eaten by $M$. nitidulum (20.8 \pm $2.5 \mathrm{~mm}$ SL) for 3 prey species: Calanus sinicus ( 0.6 to 0.8 vs 0.4 to $0.6 \mathrm{~mm}$ carapace width), Calanus spp. (0.5 to 0.8 vs 0.3 to $0.6 \mathrm{~mm}$ ) and Corycaeus spp. (0.3 to 0.4 vs 0.1 to $0.2 \mathrm{~mm}$ ) (U-test, p < 0.05). All 4 species fed on Calanus and Paracalanus spp., probably because they are very abundant in Kuroshio surface waters (Kidachi \& Ito 1979, Nakata 1997).

The amphipod Lestrigonus schizogeneios was consumed by all 4 species, accounting for 91 to $100 \%$ of the total number of amphipods identified in stomachs (Table 1). The individuals found in Myctophum nitidulum stomachs were significantly smaller than those eaten by $M$. asperum $(0.9$ vs $0.5 \mathrm{~mm}$ mean carapace width, $U$-test, $\mathrm{p}<0.05)$, which is similar to the calanoid copepods mentioned above. However, Platyscelus serratulus, the size of which was 1.5 to 2 times larger than L. schizogeneios, was eaten only by $M$. nitidulum.

Symbolophorus evermanni ate primarily euphausiids, in particular Euphausia similis and E. nana (Table 1). Most of the Euphausia consumed by the other 3 species were less than $12.3 \mathrm{~mm}$ in total length and therefore probably E. nana.

The pteropods that we identified were all Clio pyramidata and were consumed only by Centrobranchus brevirostris (Table 1).
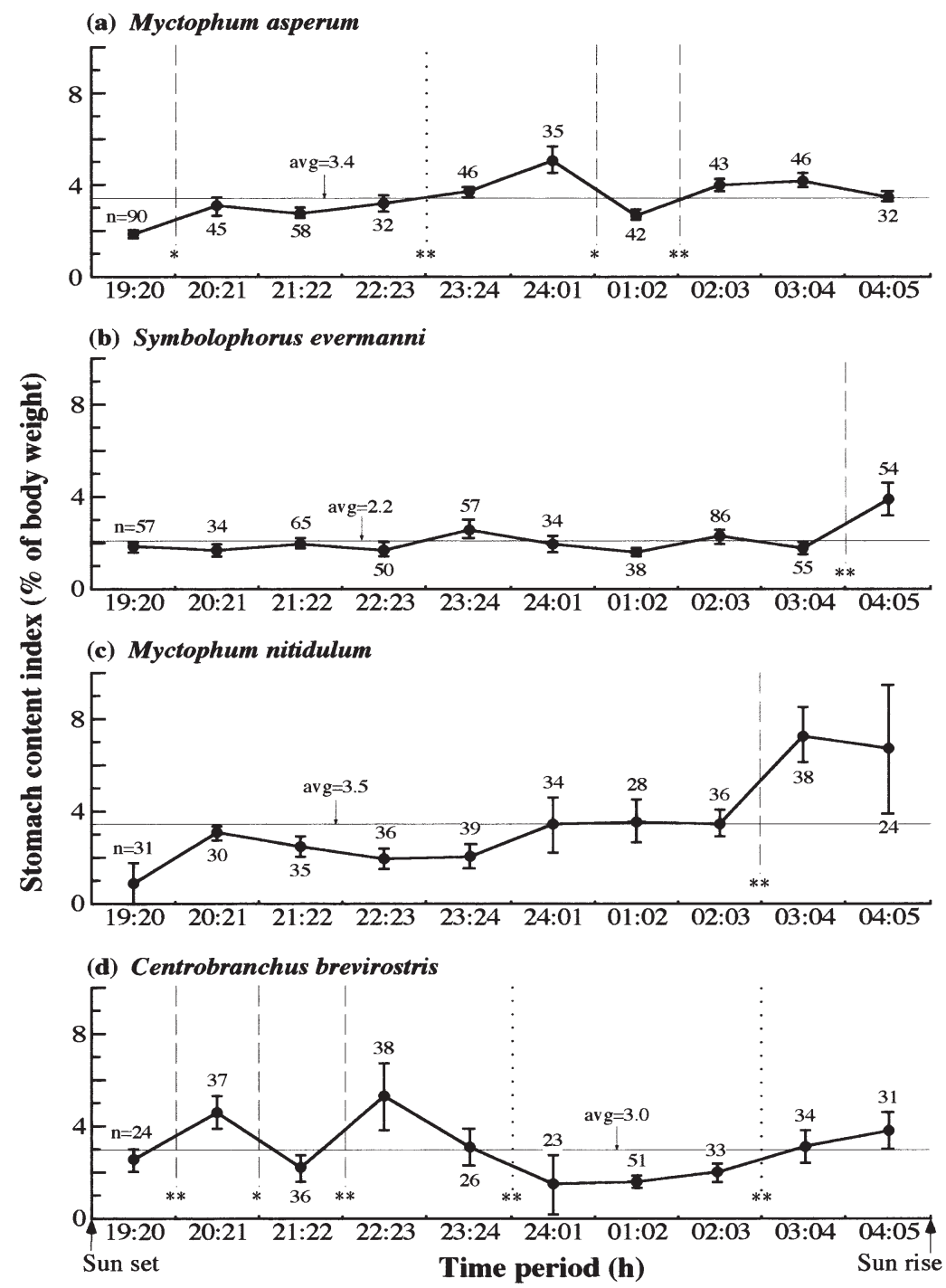

Fig. 4. Temporal change in stomach content weight at night (SCI), given as percentage of fish body weight, for: (a) Myctophum asperum; (b) Symbolophorus evermanni; (c) Myctophum nitidulum; and (d) Centrobranchus brevirostris. $\mathrm{n}$ indicates the number of stomachs examined. Vertical bars indicate \pm SE. Broken lines indicate a significant difference between both sides of the line; dotted lines indicate a significant difference between the peak value and the values $2 \mathrm{~h}$ before or after the peak $\left(U\right.$-test, $\left.{ }^{*} \mathrm{p}<0.01,{ }^{* *} \mathrm{p}<0.05\right)$ 


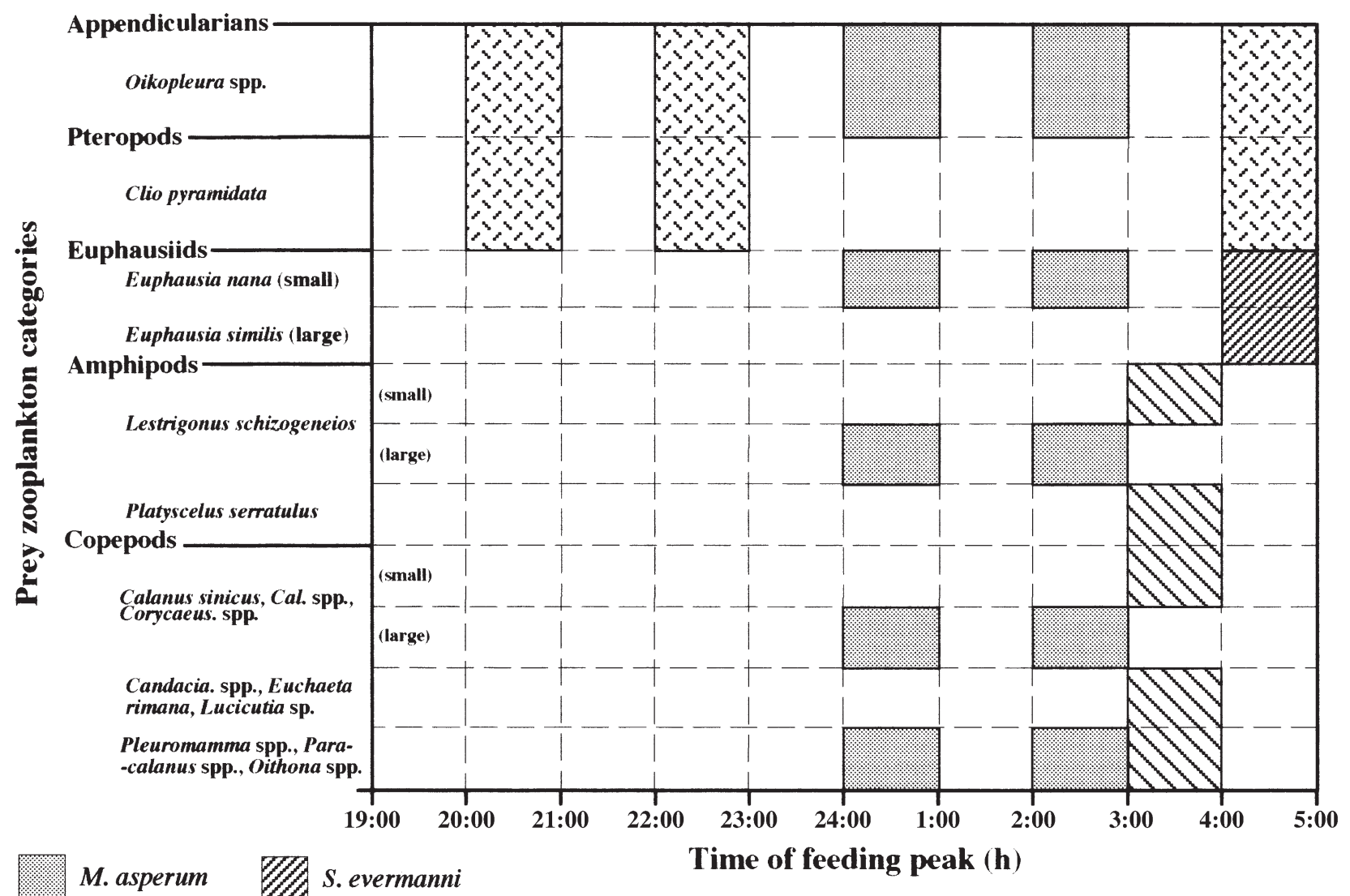

M. nitidulum

$\therefore 3$ C. brevirostris

Fig. 5. Relationship among the main prey categories, their sizes and feeding peaks for the 4 myctophid fishes, Myctophum asperum, Symbolophorus evermanni, Myctophum nitidulum and Centrobranchus brevirostris

These data indicate that the 3 species have gill raker intervals small enough to retain small copepods such as Paracalanus and Oithona spp. (Table 1). However, some prey species or genera were segregated by size and fish species, indicating that the fishes feed selectively in the top $1 \mathrm{~m}$ water layer at night rather than randomly filtering water through gill rakers.

\section{Feeding chronology}

Changes in SCI by the hour at night (feeding chronology) showed species-specific patterns of feeding activity (Fig. 4).

\section{Myctophum asperum}

Feeding peaks were from 24:00 to $01: 00 \mathrm{~h}(5.1 \% \mathrm{SCI})$ and $02: 00$ to $03: 00 \mathrm{~h}(4.0 \% \mathrm{SCI})$ (Fig. $4 \mathrm{a})$. The SCI for $01: 00$ to $02: 00 \mathrm{~h}(2.7 \%)$ was significantly lower than the SCI values immediately before and after ( $U$-test, $\mathrm{p}<0.01$ and $\mathrm{p}<0.05)$.

\section{Symbolophorus evermanni}

Feeding activity fluctuated around the mean $(2.2 \%$ SCI) throughout the night, with a significant peak $(3.9 \%)$ at dawn $(04: 00$ to $05: 00 \mathrm{~h})(U$-test, p $<0.05)$ (Fig. 4b).

\section{Myctophum nitidulum}

SCI values were below the mean (3.5\%) before $24: 00 \mathrm{~h}$ but increased gradually to the peak $(7.3 \%)$ from 03:00 to 04:00 h (Fig. 4c).

\section{Centrobranchus brevirostris}

Two notable peaks, 1.5 to 1.8 times higher than the mean $(3.0 \% \mathrm{SCI})$, occurred from $20: 00$ to $21: 00 \mathrm{~h}$ $(4.6 \%)$ and from $22: 00$ to $23: 00 \mathrm{~h}(5.3 \%)$ (Fig. $4 \mathrm{~d})$. The SCI values decreased to $1.5 \%$ from $24: 00$ to $01: 00 \mathrm{~h}$ and then gradually increased to $3.8 \%$ from 04:00 to 05:00 h (Fig. 4d). 


\section{Resource partitioning}

Fig. 5 shows the major prey items of the 4 species in relation to the peak feeding hours in Fig. 4. There was no overlap of main prey category or peak feeding time among the 4 species, suggesting that trophic competition is reduced because the species differ in prey type, prey size and peak feeding hours in the upper $1 \mathrm{~m}$ layer during the night (Fig. 5).

\section{DISCUSSION}

\section{Resource partitioning}

Other myctophid species in the subtropical and tropical Atlantic and Pacific Oceans choose the species and size of their prey (Merrett \& Roe 1974, Clarke 1980, Roe \& Badcock 1984, Hopkins \& Baird 1985, Hopkins \& Gartner 1992). The myctophid fish studied here appear to behave similarly to such species, except that they do not engage in opportunistic, random filter feeding. Because their gill raker slits are small enough to filter prey of all sizes (as shown by the stomach contents), random filter feeding does not explain why Myctophum asperum, Symbolophorus evermanni and $M$. nitidulum consume different prey. Microscale spatiotemporal distributions of each prey organism and each myctophid species are required to explain the mechanisms of the observed resource partitioning in the surface layer of the open sea.

\section{Peak feeding hours}

The myctophid species in this study differ in peak feeding time, as do fish found off Hawaii, in the tropical western Pacific, in the transitional western North Pacific, and in the subtropical eastern North Atlantic (Merrett \& Roe 1974, Gorelova 1975, Clarke 1978, Roe \& Badcock 1984, Kawamura \& Fujii 1988). However, our nighttime catches of the 4 myctophid species did not significantly differ by the hour $(\mathrm{H}$. Watanabe unpubl. data), suggesting that the density of myctophids that migrate to surface waters is maintained throughout the night in the upper $1 \mathrm{~m}$ layer in the waters of the Kuroshio region. Similar results have been reported for Myctophum nitidulum in this study area (Hattori 1964). The nighttime densities of some species of copepods, euphausiids and amphipods in the surface layer, however, are known to change with time according to the species' vertical migration in the equatorial and subarctic areas of the Pacific Ocean and the Southern China Sea (Roger 1971, Roe 1984, Roe et al. 1984, Williams \& Conway 1984, Hirota 1987, Hattori
1989). Thus, prey density and composition probably fluctuate temporally during the night in the top $1 \mathrm{~m}$ layer of the open sea. The feeding activity of myctophids that migrate vertically over the day and night usually peaks when prey density in the habitat is highest (Clarke 1978, Roe \& Badcock 1984, Kinzer \& Schulz 1985). Therefore, the chronology of nocturnal feeding by myctophids that migrate to the surface may be affected by temporal changes in zooplankton density and also by the feeding condition (such as being full versus hungry) of the fishes themselves. Notably, $M$. asperum and Centrobranchus brevirostris, the species that consume gelatinous plankton, had 2 and 3 feeding peaks, respectively (Fig. 4). These species probably digest these low-nutrient, gelatinous prey quickly and thus need to ingest large numbers of them.

\section{Prey organisms}

Some myctophids (such as Lampanyctus alatus, Bolinichthys longipes, Diaphus perspicillatus and Ceratoscopelus warmingi) that migrate to midwaters feed frequently on pigmented copepods belonging to Euchaeta, Pleuromamma, Candacia and Oncaea (Gorelova 1978, Clarke 1980, Hopkins \& Baird 1985, Kinzer et al. 1993). This diet has also been reported in the equatorial Pacific for species such as Myctophum spinosum and $M$. nitidulum that migrate to surface waters (Gorelova 1975). However, the species in this study that migrate to the surface fed mostly on nonpigmented Paracalanus copepods, probably because these copepods are abundant in Kuroshio surface waters (Kidachi \& Ito 1979, Nakata 1997).

Centrobranchus also consumes gelatinous zooplankton in the Gulf of Mexico (C. nigrocellatus; Hopkins \& Gartner 1992) and the tropical western North Pacific (C. andreae; Gorelova 1975). The stub-like degenerated gill raker that is diagnostic of this genus (Bekker 1966) very likely evolved as a result of exclusive feeding on gelatinous zooplankton, especially pteropods.

\section{Impact of predation by myctophids on surface zooplankton biomass}

Myctophids that migrate to the surface excrete food about 2 to $4 \mathrm{~h}$ after feeding in subtropical and tropical waters where temperatures range between 13 and $22^{\circ} \mathrm{C}$ (Gorelova 1975, 1984, Clarke 1978). Mean surface water temperatures at the stations at which Myctophum asperum, Symbolophorus evermanni, $M$. nitidulum and Centrobranchus brevirostris were sampled are $18.2^{\circ} \mathrm{C}$ (ranging from 11.6 to $22.6^{\circ} \mathrm{C} ; \mathrm{n}=3348$ ), $18.4^{\circ} \mathrm{C}\left(11.5\right.$ to $\left.22.3^{\circ} \mathrm{C} ; \mathrm{n}=2101\right), 18.0^{\circ} \mathrm{C}\left(7.3\right.$ to $22.6^{\circ} \mathrm{C}$; 
Table 2. Estimates of the predation impact on zooplankton by the 4 species Myctophum asperum, Symbolophorus evermanni, Myctophum nitidulum and Centrobranchus brevirostris per night in the top $5 \mathrm{~m}$ in the Kuroshio Current region from January to March in 1971, 1973, 1977, 1980 and 1984. ${ }^{*}$ Mean zooplankton biomass (wet weight) in the top $150 \mathrm{~m}$ of the studied area from January to March (Kuroda 1991), ${ }^{* *}$ biomass (wet weight) of each myctophid species in the top 5 m at night (Watanabe 1998)

\begin{tabular}{|c|c|c|c|c|c|}
\hline & M. asperum & S. evermanni & M. nitidulum & C. brevirostris & $\begin{array}{l}\text { Total } \\
\text { of the } 4 \text { species }\end{array}$ \\
\hline Nighttime ration ( $\%$ of body weight) & $8.1-12.5$ & $5.1-8.5$ & $9.7-14.0$ & $7.1-12.2$ & - \\
\hline \multicolumn{6}{|l|}{$\begin{array}{l}1971 \\
\text { Zooplankton biomass } 111 \mathrm{mg} \mathrm{m}^{-3 *}\end{array}$} \\
\hline Myctophid biomass $\left(\mathrm{mg} \mathrm{m}^{-3}\right)^{* *}$ & 31.2 & 42.1 & 14.0 & 21.8 & 109.0 \\
\hline Nighttime ration $\left(\mathrm{mg} \mathrm{m}^{-3}\right)$ & $2.53-3.90$ & $2.15-3.58$ & $1.36-1.96$ & $1.55-2.66$ & $7.59-12.10$ \\
\hline Predation impact (\% of $111 \mathrm{mg} \mathrm{m}^{-3}$ ) & $2.28-3.51$ & $1.94-3.23$ & $1.23-1.77$ & $1.40-2.40$ & $6.84-10.90$ \\
\hline \multicolumn{6}{|l|}{$\begin{array}{l}1973 \\
\text { Zooplankton biomass } 69 \mathrm{mg} \mathrm{m}^{-3 *}\end{array}$} \\
\hline Myctophid biomass $\left(\mathrm{mg} \mathrm{m}^{-3}\right)^{* *}$ & 8.7 & 12.0 & 1.7 & 1.7 & 24.0 \\
\hline Nighttime ration $\left(\mathrm{mg} \mathrm{m}^{-3}\right)$ & $0.70-1.09$ & $0.61-1.02$ & $0.16-0.24$ & $0.12-0.21$ & $1.59-2.56$ \\
\hline Predation impact ( $\%$ of $69 \mathrm{mg} \mathrm{m}^{-3}$ ) & $1.01-1.58$ & $0.88-1.48$ & $0.23-0.35$ & $0.17-0.30$ & $2.30-3.71$ \\
\hline \multicolumn{6}{|l|}{$\begin{array}{l}1977 \\
\text { Zooplankton biomass } 38 \mathrm{mg} \mathrm{m}^{-3 *}\end{array}$} \\
\hline Myctophid biomass $\left(\mathrm{mg} \mathrm{m}^{-3}\right)^{* *}$ & 4.4 & 3.4 & 3.3 & 0.9 & 12.0 \\
\hline Nighttime ration $\left(\mathrm{mg} \mathrm{m}^{-3}\right)$ & $0.36-0.55$ & $0.17-0.29$ & $0.32-0.46$ & $0.06-0.11$ & $0.91-1.41$ \\
\hline Predation impact ( $\%$ of $38 \mathrm{mg} \mathrm{m}^{-3}$ ) & $0.95-1.45$ & $0.45-0.76$ & $0.84-1.21$ & $0.16-0.29$ & $2.39-3.71$ \\
\hline \multicolumn{6}{|l|}{$\begin{array}{l}1980 \\
\text { Zooplankton biomass } 53 \mathrm{mg} \mathrm{m}^{-3 *}\end{array}$} \\
\hline Myctophid biomass $\left(\mathrm{mg} \mathrm{m}^{-3}\right)^{* * *}$ & 3.6 & 2.1 & 0.3 & 0.5 & 6.5 \\
\hline Nighttime ration $\left(\mathrm{mg} \mathrm{m}^{-3}\right)$ & $0.29-0.45$ & $0.11-0.18$ & $0.03-0.04$ & $0.04-0.06$ & $0.47-0.73$ \\
\hline Predation impact ( $\%$ of $53 \mathrm{mg} \mathrm{m}^{-3}$ ) & $0.55-0.85$ & $0.21-0.34$ & $0.06-0.08$ & $0.08-0.11$ & $0.89-1.38$ \\
\hline \multicolumn{6}{|l|}{$\begin{array}{l}1984 \\
\text { Zooplankton biomass } 30 \mathrm{mg} \mathrm{m}^{-3 *}\end{array}$} \\
\hline Myctophid biomass $\left(\mathrm{mg} \mathrm{m}^{-3}\right)^{* *}$ & 3.2 & 10.0 & 0.6 & 1.5 & 15.3 \\
\hline Nighttime ration $\left(\mathrm{mg} \mathrm{m}^{-3}\right)$ & $0.26-0.40$ & $0.51-0.85$ & $0.06-0.08$ & $0.11-0.18$ & $0.94-1.51$ \\
\hline Predation impact ( $\%$ of $30 \mathrm{mg} \mathrm{m}^{-3}$ ) & $0.87-1.33$ & $1.70-2.83$ & $0.20-0.27$ & $0.37-0.60$ & $3.13-5.03$ \\
\hline
\end{tabular}

$\mathrm{n}=525)$ and $18.9^{\circ} \mathrm{C}\left(14.3\right.$ to $\left.22.3^{\circ} \mathrm{C} ; \mathrm{n}=522\right)$, respectively (Watanabe 1998). At these temperatures, the time to excretion would be about 2 to $4 \mathrm{~h}$ after feeding. We assumed a time to excretion of $4 \mathrm{~h}$ and estimated the impact of predation on zooplankton biomass by summing the highest SCI values observed from 19:00 to $23: 00 \mathrm{~h}, 23: 00$ to $03: 00 \mathrm{~h}$ and $03: 00$ to $05: 00 \mathrm{~h}$. We estimated a maximum predation impact of $12.5 \%$ for M. asperum at night, based on interval estimates of $3.2 \%$ (from 19:00 to $23: 00 \mathrm{~h}$ ), $5.1 \%$ (from 23:00 to 03:00 h) and 4.2\% (from 03:00 to 05:00 h). Similarly, we used sums of the lowest SCI values $(1.9 \%, 2.7 \%$ and $3.5 \%)$ over these same 3 time periods to estimate $8.1 \%$ as the minimum predation impact. Thus, we estimate that $M$. asperum consumed 8.1 to $12.5 \%$ of its body weight in zooplankton biomass per night. Based on similar calculations, nighttime zooplankton rations were estimated as 5.1 to $8.5 \%$ for $S$. evermanni, 9.7 to $14.0 \%$ for $M$. nitidulum and 7.1 to $12.2 \%$ for $C$. brevirostris. Considering that migratory myctophid fishes generally feed mainly at night in subtropical and tropical waters (Gorelova 1973, Baird et al. 1975, Clarke 1978, Hopkins \& Baird 1985, Kinzer \& Schulz 1985), these values are valid estimates of the daily rations for these species. Gorelova (1984) reported that daily rations of juvenile surface migratory myctophids such as $M$. asperum, M. spinosum and Hygophum proximum (17 to $28 \mathrm{~mm} \mathrm{SL}$ ) in the tropical waters of the Pacific are approximately 10 to $20 \%$ of the body wet wt. This estimate is almost 1.5 to 2 times of magnitude higher than our estimate for the Kuroshio region in the western North Pacific.

The biomass of myctophids that migrate to surface waters was estimated for the top $5 \mathrm{~m}$ in the studied area from 1971 to 1984 (Watanabe 1998). Zooplankton biomass in the upper $150 \mathrm{~m}$ was measured at each myctophid sampling station (Kuroda 1991). Based on these biomass data, we estimated the zooplankton biomass consumed by the 4 myctophid species per night, and their feeding impact, for 5 years between 1971 and 1984 (Table 2). Our calculations indicate that, by consuming individuals of 10 to $30 \mathrm{~mm} \mathrm{SL}$, the 4 species removed 2.30 to $3.71 \%, 2.39$ to $3.71 \%, 0.89$ to $1.38 \%$ and 3.13 to $5.05 \%$ of the total zooplankton biomass per night in the top $150 \mathrm{~m}$ during 1973, 1977, 1980 and 1984, respectively (Table 2). Hopkins \& 
Gartner (1992) reported that predation by myctophids removes $2 \%$ of the zooplankton biomass per night in the upper $200 \mathrm{~m}$ of the eastern Gulf of Mexico. This value takes into account predation by species that migrate to both surface and midwaters, so the impact on zooplankton of nocturnal predation by myctophids that migrate to the surface is higher in the Kuroshio region of the western North Pacific than in the Gulf of Mexico. In 1971, zooplankton biomass from January to March in the study area was 1.5 to 3 times greater than in any other year from 1972 to 1988 (Kuroda 1991) and biomass of the 4 myctophid species was 4 to 15 times greater in 1971 than in any other year from 1957 to 1988 (Watanabe 1998). Thus, our estimate of predation impact of 6.84 to $10.90 \%$ by the 4 species combined for 1971 (Table 2) is probably so high because recruitment was high; Japanese sardine recruitment was also high in 1971, the year that the biomass began to rebound.

Acknowledgements. We are grateful to Drs. K. Mori, J. Kosaka, T. Mitani and M. Ishida of the Japanese Fisheries Agency (JFA) and Professor Y. Watanabe of the Ocean Research Institute, University of Tokyo, for allowing us to examine the samples housed at the JFA.

\section{LITERATURE CITED}

Baird RC, Hopkins TL, Wilson DF (1975) Diet and feeding chronology of Diaphus taaningi (Myctophidae) in the Cariaco Trench. Copeia 2:356-365

Bekker VE (1966) Slendertailed luminescent anchovies (genera Lowenia, Tarletonbeania, Gonichthys, and Centrobranchus) of the Pacific and Indian Oceans: systematics and distribution. In: Rass TS (ed) Fishes of the Pacific and Indian Oceans: biology and distribution. Israel Program for Scientific Translations, Jerusalem, p 10-78

Clarke TA (1978) Diel feeding patterns of 16 species of mesopelagic fishes from Hawaiian waters. Fish Bull US 76:495-513

Clarke TA (1980) Diets of fourteen species of vertically migrating mesopelagic fishes in Hawaiian waters. Fish Bull US 78:619-640

Gorelova TA (1973) Zooplankton from the stomachs of juvenile lanternfish of the family Myctophidae. Oceanology 14:575-579

Gorelova TA (1975) The feeding of fishes of the family Myctophidae. J Ichthyol 15:208-219

Gorelova TA (1978) Nutrition of the luminescent anchovies, Ceratoscopelus warmingi (Lutken) and Bolinichthys longipes (Brauer) fam. Myctophidae in the western equatorial part of the Pacific Ocean. J Ichthyol 18:673-683

Gorelova TA (1984) A quantitative assessment of consumption of zooplankton by epipelagic lanternfishes (family Myctophidae) in the equatorial Pacific Ocean. J Ichthyol 23:106-113

Hattori H (1989) Bimodal vertical distribution and diel migration of the copepods Metridia pacifica, M. okhotensis and Pleuromamma schtullata in the western North Pacific Ocean. Mar Biol 103:39-50

Hattori S (1964) Studies on fish larvae in the Kuroshio and adjacent waters. Bull Tokai Reg Fish Res Lab 40:1-111 (in Japanese with English abstract)

Hirota Y (1987) Vertical distribution of euphausiids in the western Pacific Ocean and the eastern Indian Ocean. Bull Jpn Sea Reg Fish Res Lab 37:175-224

Hirota Y, Nemoto T, Marumo R (1984) Vertical distribution of larvae of Euphausia nana and E. similes (Crustacea: Euphausiacea) in Sagami Bay and Suruga Bay, central Japan. Mar Biol 81:131-137

Hopkins TL, Baird RC (1985) Aspects of the trophic ecology of the mesopelagic fish Lampanyctus alatus (family Myctophidae) in the eastern Gulf of Mexico. Biol Oceanogr 3: 285-313

Hopkins TL, Gartner JV Jr (1992) Resource-partitioning and predation impact of a low-latitude myctophid community. Mar Biol 114:185-197

Kawaguchi K, Ikeda H, Tamura M, Ueyanagi S (1972) Geographical distribution of surface-migrating myctophid fishes (genus Myctophum) in the tropical and subtropical Pacific and Indian Oceans. Bull Natl Res Inst Far Seas Fish 6:23-37

Kawamura A, Fujii F (1988) Forage of the mesopelagic fishes, Symbolophorus californiensis (Eigenmann \& Eigenmann) and Tarletonbeania taylori Mead caught in gill nets in the northwestern North Pacific Ocean. Bull Ocean Res Inst Univ Tokyo 26(Part II):143-159

Kidachi T, Ito H (1979) Distribution and structure of macroplankton communities in the Kuroshio and coastal region, south of Hoshu, during spring season. Bull Tokai Reg Fish Res Lab 97:1-119 (in Japanese with English abstract)

Kidachi T, Yamamoto T, Ito H (1983) Characteristics of macroplankton community in the Kuroshio area, south of Shionomisaki, March 1967. Bull Tokai Reg Fish Res Lab 112: 27-48 (in Japanese with English abstract)

Kinzer J, Schulz K (1985) Vertical distribution and feeding patterns of midwater fish in the central equatorial Atlantic. Mar Biol 85:313-322

Kinzer J, Böttger-Schnack R, Schulz K (1993) Aspects of horizontal distribution and diet of myctophid fish in the Arabian Sea with reference to the deep water oxygen deficiency. Deep-Sea Res 40:783-800

Kuroda K (1991) Studies on the recruitment process focusing on the early life history of the Japanese sardine, Sardinops melanostictus (Schlegel). Bull Natl Res Inst Fish Sci 3: 25-278 (in Japanese with English abstract)

Loeb VJ (1979) Larval fishes in the zooplankton community of the north Pacific central gyre. Mar Biol 53:173-191

Loeb VJ (1980) Patterns of spatial and species abundance within the larval fish assemblage of the north Pacific central gyer during late summer. Mar Biol 60:189-200

Merrett NR, Roe HSJ (1974) Patterns and selectivity in the feeding of certain mesopelagic fishes. Mar Biol 28: $115-126$

Moku M, Kawaguchi K, Watanabe H, Ohno A (2000) Feeding habits of three dominant myctophid fishes, Diaphus theta, Stenobrachius leucopsarus and S. nannochir, in the subarctic and transitional waters of the western North Pacific. Mar Ecol Prog Ser 207:129-140

Moser HJ, Smith PE (1993) Larval fish assemblages of the California Current region and their horizontal and vertical distributions across a front. Bull Mar Sci 53:645-691

Nakai Z (1962) Apparatus for collecting macroplankton in the spawning surveys of iwashi (sardine, anchovy, and round herring) and others. Bull Tokai Reg Fish Res Lab 9: 221-237

Nakata K (1997) Studies on the food availability for larvae of the Japanese sardine in and near the Kuroshio. Bull Natl 
Res Inst Fish Sci 9:19-128 (in Japanese with English abstract)

Ogawa T (1961) Study on the fishes of the family Myctophidae in the north-eastern sea area along the Pacific coast of Japan. Part I. Species and distribution. Bull Tohoku Reg Fish Res Lab 19:81-89 (in Japanese with English abstract)

Paxton J (1972) Osteology and relationships of the lanternfishes (family Myctophidae). Bull Los Angel Cty Mus Nat Hist Sci 13:1-81

Pearcy WG, Lorz HV, Peterson W (1979) Comparison of the feeding habits of migratory and non-migratory Stenobrachius leucopsarus (Myctophidae). Mar Biol 51:1-8

Roe HSJ (1984) The diel migrations and distributions within a mesopelagic community in the north east Atlantic. 4. The copepods. Prog Oceanogr 13:353-388

Roe HSJ, Badcock J (1984) The diel migrations and distributions within a mesopelagic community in the north east Atlantic. 5. Vertical migrations and feeding of fish. Prog Oceanogr 13:389-424

Editorial responsibility: Otto Kinne (Editor), Oldendorf/Luhe, Germany
Roe HSJ, James PT, Thurston MH (1984) The diel migrations and distributions within a mesopelagic community in the north east Atlantic. 6. Medusae, ctenophores, amphipods, and euphausiids. Prog Oceanogr 13:425-460

Roger C (1971) Vertical distribution of euphausiids (crustaceans) in the equatorial currents of the Pacific Ocean. Mar Biol 10:134-144

Tyler HR Jr, Pearcy WG (1975) The feeding habits of three species of lanternfishes (family Myctophidae) off Oregon, USA. Mar Biol 32:7-11

Watanabe H (1998) Ecological study of the surface migratory myctophid fishes in the Kuroshio and its adjacent region. PhD thesis, University of Tokyo (in Japanese)

Watanabe H, Kawaguchi K (1999) The effect of towing bridles on net avoidance by micronektonic fishes in nighttime neuston sampling. Bull Jpn Soc Fish Oceanogr 63:1-5

Williams R, Conway DVP (1984) Vertical distribution, and seasonal and diurnal migration of Calanus helgolandicus in the Celtic Sea. Mar Biol 79:63-73

Submitted: October 5, 2001; Accepted: February 19, 2002 Proofs received from author(s): May 28, 2002 